\title{
A single-ion gel polymer electrolyte based on polymeric lithium tartaric acid borate and its superior battery performance
}

\author{
Xuejiang Wang, Zhihong Liu* ${ }^{*}$, Qingshan Kong, Wen Jiang, Jianhua Yao, Chuanjian Zhang, Guanglei Cui * \\ Qingdao Institute of Bioenergy and Bioprocess Technology, Chinese Academy of Sciences, Qingdao 266101, China
}

\section{A R T I C L E I N F O}

\section{Article history:}

Received 6 May 2013

Received in revised form 2 September 2013

Accepted 7 September 2013

Available online 30 September 2013

\section{Keywords:}

Gel polymer electrolyte

Lithium salt

Ionic conductivity

Single-ion electrolyte

Lithium ion battery

\begin{abstract}
A B S T R A C T
A single-ion gel polymer electrolyte of PLTB@PVDF-HFP (polymeric lithium tartaric acid borate@poly(vinylidene fluoride-co-hexafluoropropene)) was prepared and its ionic conductivity was optimized via solvent composition tailoring. It was manifested that the ethylene carbonate/dimethyl carbonate (EC/DMC) swollen PLTB@PVDF-HFP exhibited a superior lithium ionic conductivity at room temperature to that of the traditional liquid electrolyte system ( $1 \mathrm{M} \mathrm{LiPF}_{6} / \mathrm{EC} / \mathrm{DMC}$ ). The $\mathrm{Li}_{4} \mathrm{Ti}_{5} \mathrm{O}_{12} / \mathrm{LiFePO}_{4}$ cells using the EC/DMC swollen PLTB@PVDF-HFP as polymer electrolyte showed stable charge/discharge voltage profiles with small voltage hysteresis, preferable rate capability and excellent cycle performance at room temperature. These superior performances of EC/DMC swollen PLTB@ PVDF-HFP could endow this class of gel polymer electrolyte a very promising alternative to state of the art liquid electrolyte system.
\end{abstract}

(c) 2013 Elsevier B.V. All rights reserved.

\section{Introduction}

Lithium ion batteries have been attracted much attention in the last decade for their potential application for electric vehicles (EVs), hybrid electric vehicles (HEVs) and smart grid [1,2]. However, the largecapacity battery modulus claims more safety concerns, because fire or explosion at abnormal conditions may lead to serious hazards owing to the hidden peril of traditional liquid electrolyte system, i.e., lithium hexafluorophosphate solutions in aprotic organic solvents. This traditional liquid electrolyte system has been widely used in state of the art technology mainly owing to its high ionic conductivity $\left(10^{-3}-10^{-2} \mathrm{~S} \mathrm{~cm}{ }^{-1}\right)$ at room temperature [3-9]. The use of a gel polymer electrolyte (GPE) in place of the liquid electrolyte may help to tackle safety concerns: (i) suppression of lithium dendrite growth that is usually caused by uneven currents when charged in the case of porous separators. (ii) Alleviation of interfacial reactivity between the electrode and liquid electrolytes due to the least use of alkyl carbonate solvents. (iii) Improvement of safety, in addition to suppression of lithium dendrites, the quasi-solid-state construction of a polymer electrolyte is more tolerant to mechanical deformation. (iv) Better shape flexibility and manufacturing integrity [10-17]. Meanwhile, to be successfully used in practice, GPE must meet the following basic requirements: (i) ionic conductivity higher than $\sim 10^{-4} \mathrm{~S} \mathrm{~cm}^{-1}$ at room temperature, (ii) lithium ion transference number close to unity, (iii) good thermal, chemical and electrochemical stability and (iv) a considerable mechanical strength [10,12,18-21]. However, rare GPEs have been reported to accomplish all above standards.

\footnotetext{
* Corresponding authors. Tel.: + 86532 80662746; fax: + 8653280662744.

E-mail addresses: liuzh@qibebt.ac.cn (Z. Liu), cuigl@qibebt.ac.cn (G. Cui).
}

Lithium hexafluorophosphate $\left(\mathrm{LiPF}_{6}\right)$ is predominant lithium salt in liquid electrolyte system $[9,10]$. However, $\mathrm{LiPF}_{6}$ is known to be extremely sensitive to moisture and thermally decompose at about $60{ }^{\circ} \mathrm{C}$. Its decomposition components consist of high toxic and corrosive $\mathrm{HF}^{\circ} \mathrm{PF}_{5}$ and $\mathrm{POF}_{3}$, where $\mathrm{HF}$ can dissolve cathode active materials, $\mathrm{PF}_{5}$ can react with electrolyte solvents and consequently bring about thermal runaway [22-24]. In the last few years, a kind of lithium borate salts, for example, lithium bis(oxalato) borate (LiBOB) has attracted great interest to researchers because of superior thermal stability, considerable ionic conductivity and fair dissociation constant [25-27]. Furthermore, some kinds of polymer electrolytes based on chelate compound with boron were also reported. Angell et al. have developed polymer electrolytes based on hybrid composition of LiBOB and poly(ethylene glycol)s (PEGs) with the ionic conductivities reaching $\sim 10^{-5} \mathrm{~S} \mathrm{~cm}^{-1}$ at room temperature. And the lithium ion transference number was far away from the theoretical value even for the polyanionic solid electrolytes, owing to the presence of some anion impurity produced unavoidably during synthesis [28-30]. Two kinds of single-ion polymer electrolytes, lithium oxalate polyacrylic acid borate (LiPAAOB) and lithium polyvinyl alcohol oxalate borate (LiPVAOB) were very recently synthesized by $\mathrm{Wu}$ Y. P. et al. [31,32]. While, the ionic conductivities for both of them could only reach $\sim 10^{-6} \mathrm{~S} \mathrm{~cm}^{-1}$ at room temperature, far away from the requirement for applicable polymer electrolytes for rechargeable lithium ion batteries.

In our previous report, a novel kind of "main-chain" type polymeric lithium tartaric acid borate (PLTB, Fig. 1(a)) was synthesized via a onestep reaction in aqueous solution [33]. The as-prepared PLTB possesses a high thermal decomposition temperature at $330^{\circ} \mathrm{C}$. The GPE of PLTB@ PVDF-HFP was developed by a doctor-blading followed by a soaking process in propylene carbonate (PC). It was manifested that the PC 
(a)

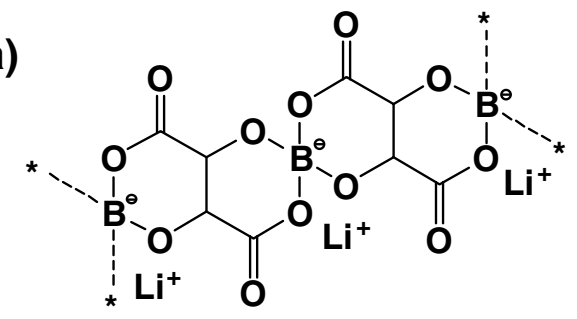

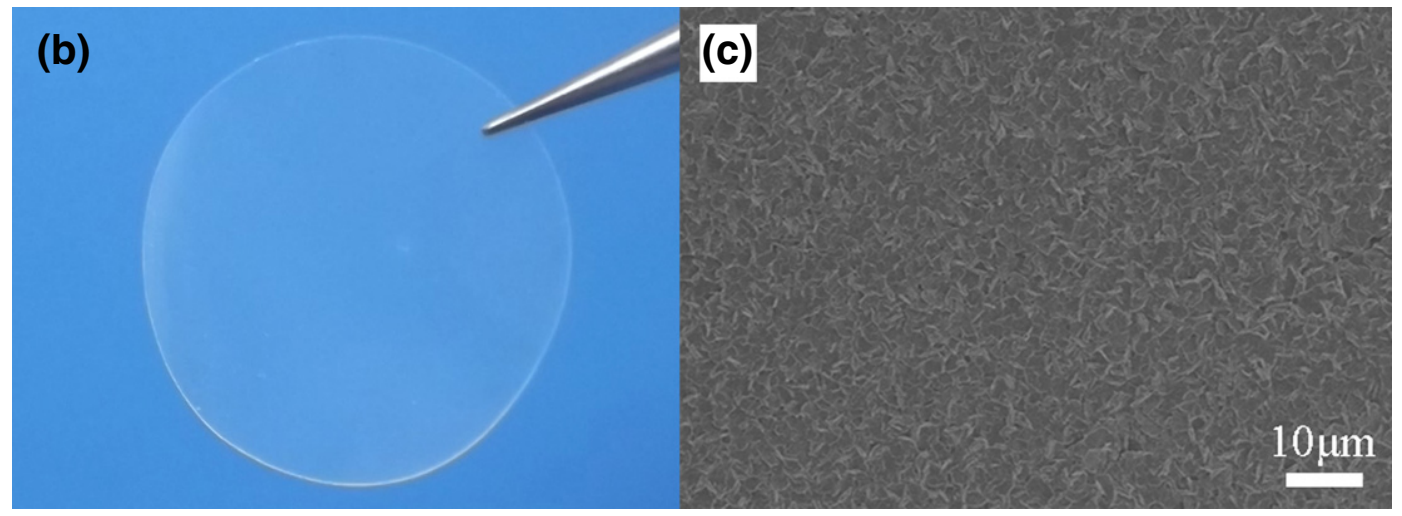

Fig. 1. (a) Chemical structure of the polymeric lithium tartaric acid borate (PLTB), (b) photograph of the PLTB@PVDF-HFP membrane and (c) its surface morphology observed by SEM.

swollen PLTB@PVDF-HFP exhibited excellent properties at an operating temperature of $80^{\circ} \mathrm{C}$. However, PC swollen PLTB@PVDF-HFP suffered poor rate capability at room temperature, which would limit its extensive application because most of battery devices are indeed operated at ambient temperature. In this paper, we optimized the ion conductivity of PLTB@PVDF-HFP membranes in mixed solvents instead of PC to further improve the ionic conductivity at room temperature. The battery properties including charge/discharge behavior, rate capability and cycling performance of mixed solvent swollen PLTB@PVDF-HFP were investigated in $\mathrm{Li}_{4} \mathrm{Ti}_{5} \mathrm{O}_{12} / \mathrm{LiFePO}_{4}$ full cells at room temperature. Since most of the irreversible reactions are thermally activated by the rise in temperature in an Arrhenius-like manner, their battery properties were also compared with those of the traditional liquid electrolyte cells in an accelerated manner at high temperature of $60^{\circ} \mathrm{C}$.

\section{Experimental}

\subsection{Materials}

Ethylene carbonate (EC), propylene carbonate (PC) and dimethyl carbonate (DMC) (all from Capchem Technology Co., Ltd), $1 \mathrm{M} \mathrm{LiPF}_{6^{-}}$ EC/DMC (1/1, v/v, Guotai-huarong New Chemical Materials Co. Ltd.), PVDF-HFP (Aldrich, $\mathrm{M}_{\mathrm{w}} \sim 400,000, \mathrm{M}_{\mathrm{n}} \sim 130,000$, pellets, VDF: HFP 1:1), N,N-Dimethyl Formamide (99.8\%, superdry, J\&K), carboncoated $\mathrm{LiFePO}_{4}$ (Tianjin STL Energy Technology Co., Ltd.), carboncoated $\mathrm{Li}_{4} \mathrm{Ti}_{5} \mathrm{O}_{12}$ (BTR Nano Technology Co., Ltd.), PP separator (Celgard 2500). All materials were all commercially available and used without further purification.

\subsection{Preparation of mixed solvent swollen PLTB@PVDF-HFP membrane}

The procedure for the synthesis of PLTB was presented in our previous work [33]. The preparation of PLTB@PVDF-HFP membranes are described briefly as follows. PLTB and PVDF-HFP were added into DMF (N,N-dimethyl formamide) and mixed to be a transparent and homogeneous solution. Then the PLTB@PVDF-HFP membranes were prepared by a doctor-blading process under ambient atmosphere followed by a vacuum drying at $80{ }^{\circ} \mathrm{C}$ to remove DMF. Finally, PLTB@ PVDF-HFP membranes (PLTB/PVDF-HFP $=1.0 / 1.0(\mathrm{w} / \mathrm{w}), 25 \mu \mathrm{m})$ were immersed in mixed solvents to obtain the solvent swollen PLTB@PVDF-HFP membrane. The thickness of solvent swollen PLTB@ PVDF-HFP membrane was $\sim 75 \mu \mathrm{m}$.

\subsection{Characterization of mixed solvent swollen PLTB@PVDF-HFP membrane}

The surface morphology of PLTB@PVDF-HFP membrane was observed by Hitachi S-4800 field emission scanning electron microscope. The mechanical property of the membrane was measured using an Inston-3300 universal testing machine (USA) at a stretching speed of $1.66 \mathrm{~mm} / \mathrm{s}$ with the straps of about $1 \mathrm{~cm}$ wide and $5 \mathrm{~cm}$ long.

The ionic conductivity of solvent swollen PLTB@PVDF-HFP membrane between two stainless-steel plate electrodes was obtained by an AC impedance analysis using a Zahner Zennium electrochemical working station over a frequency range of $1-10^{6} \mathrm{~Hz}$ with a perturbation amplitude of $10 \mathrm{mV}$.

The electrochemical stability of solvent swollen PLTB@PVDF-HFP membrane was evaluated by a cyclic voltammetry experiment performed on a working electrode of stainless-steel and a counter electrode of lithium mental at a scan rate of $0.1 \mathrm{mV} / \mathrm{s}$. Lithium ion transference number was measured according to the method described by Evants et al. [34]. The method involved sandwiching the sample membrane in both lithium electrodes. After having measured the total initial resistance by AC impedance, a DC potential of $10 \mathrm{mV}$ was applied until a steady state was reached. Finally, the resistance was again measured by AC impedance.

$$
t^{+}=\frac{I_{S}\left(\Delta V-I_{0} R_{0}^{e l}\right)}{I_{0}\left(\Delta V-I_{S} R_{S}^{e l}\right)}
$$

where $t^{+}$is the cationic transference number, $\Delta V$ is the potential applied across the cell, $R_{0}^{e l}$ and $R_{s}^{e l}$ are the initial and steady-state resistances of the passivating layers on the Li electrode and $I_{0}$ and $I_{S}$ are the initial and steady-state currents. 


\subsection{Cell assembly and performance}

The Li/PLTB@PVDF-HFP/ $/ \mathrm{Li}_{4} \mathrm{Ti}_{5} \mathrm{O}_{12}$ half coin cells (2032-type) were assembled by sandwiching the EC/DMC (1/1, v/v) swollen PLTB@ PVDF-HFP membrane between lithium metal foil and $\mathrm{Li}_{4} \mathrm{Ti}_{5} \mathrm{O}_{12}$ electrode. The $\mathrm{Li}_{4} \mathrm{Ti}_{5} \mathrm{O}_{12} / \mathrm{PLTB} @ P V D F-H F P / L i F e P O_{4}$ full coin cells (2032type) were also assembled with $\mathrm{LiFePO}_{4}$ instead of lithium metal foil. The $\mathrm{Li}_{4} \mathrm{Ti}_{5} \mathrm{O}_{12}$ electrode was composed of $85 \mathrm{wt} . \% \mathrm{Li}_{4} \mathrm{Ti}_{5} \mathrm{O}_{12}$ (around $2.7 \mathrm{mg}$ active material on $1.54 \mathrm{~cm}^{2}$ copper metal foil), $7.5 \mathrm{wt}$.\% PVDF and 7.5 wt.\% carbon black. The $\mathrm{LiFePO}_{4}$ electrode was composed of 85 wt.\% $\mathrm{LiFePO}_{4}$ (around $3.0 \mathrm{mg}$ active material on $1.54 \mathrm{~cm}^{2}$ aluminum metal foil), 7.5 wt.\% PVDF and 7.5 wt.\% carbon black. All assembly of cells was carried out in an argon-filled glove box. After cell assembly, the cells were laid down on one side for $12 \mathrm{~h}$ and then on the other side for another $12 \mathrm{~h}$ to impregnate the porous composite electrodes and their interfaces with electrolyte. The charge/discharge, C-rate capacity and cycling ability of cells were recorded on a LAND battery test system. The galvanostatic charge/discharge behavior of Li/PLTB@ PVDF-HFP/Li $\mathrm{L}_{4} \mathrm{Ti}_{5} \mathrm{O}_{12}$ cells and $\mathrm{Li}_{4} \mathrm{Ti}_{5} \mathrm{O}_{12} / \mathrm{PLTB} @ P V D F-H F P / L i F e P O_{4}$ cells were conducted over the range of $1.0-3.0 \mathrm{~V}$ and $1.0-2.7 \mathrm{~V}$, respectively.

\section{Results and discussion}

\subsection{Characterization of PLTB@PVDF-HFP membrane}

The surface morphology of PLTB@PVDF-HFP membrane observed by SEM was depicted in Fig. 1. It could be seen that the PLTB@PVDF-HFP membrane was quite homogeneous and there was no obvious pores on the surface. The membrane exhibited tensile strength of $19 \mathrm{MPa}$ with 53\% strain (seen in Fig. S1), which indicated that the polymer electrolyte membranes possessed a considerable mechanical strength. After swollen with solvents, the gel electrolyte possessed tensile strength of 5.0 MPa with $133 \%$ strain.

3.2. Ionic conductivity optimization of PLTB@PVDF-HFP swollen in mixed solvent

It is well known that gel polymer electrolytes usually have an inferior ionic conductivity when compared with traditional liquid electrolytes, which impairs the power performance of gel polymer batteries $[9,10,18]$. Three strategies are consequently involved to improve the power performance. The first one is to tailor solvent composition for manipulating electrolyte ion conductivity due to the availability of a vast number of candidate solvents $[13,35]$. The most important are two parameters of the solvents, dielectric constant $(\varepsilon)$ and viscosity $(\eta)$, which determine the charge carrier number and ion mobility, respectively. The second one is to enhance the ionic conductivity of gel polymer electrolytes by compositing with nanoparticles including $\mathrm{SiO}_{2}$, lithium titanium phosphate, etc. [10,36]. The third one is to introduce single ionic conductor into the polymer matrices to improve the lithium ion transference number [31-33]. The as-prepared PLTB belongs to a single-ion conductor and the lithium ion transference number of PLTB@PVDF-HFP membranes can reach the theoretical value. Herein, we would like to exploit the first strategy to further improve the ionic conductivity of PLTB@PVDF-HFP membranes at room temperature through solvent composition tailoring.

Fig. 2 showed the temperature dependence of ionic conductivity for PLTB@PVDF-HFP membrane swollen in various solvents, such as PC, EC/PC $(1 / 1, v / v)$ and EC/DMC $(1 / 1, v / v)$. The mass ratio of PLTB/ PVDF-HFP/solvent was 0.5/0.5/2.0 (w/w/w). It could be seen from Fig. 2 that the membranes swollen in mixed solvent showed higher ionic conductivity as compared with the membrane swollen in pure PC solvent. The reason for the improvement of ionic conductivity in mixed solvent is related to the more rapid decrease in viscosity than the dielectric constant when the low viscosity solvent is mixed with the high dielectric constant solvent $[10,13]$. The ionic conductivities

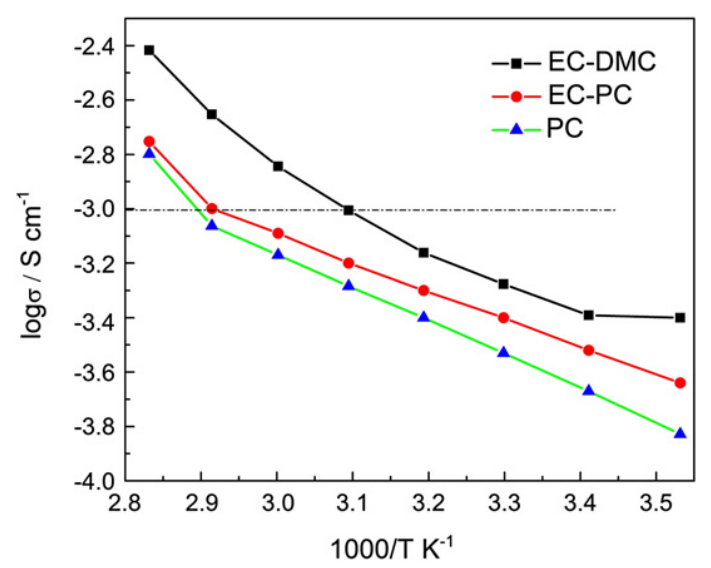

Fig. 2. Temperature dependence of ionic conductivity for PLTB@PVDF-HFP membranes swollen in various solvents. (PLTB/PVDF-HFP/solvent $=0.5 / 0.5 / 2.0, \mathrm{w} / \mathrm{w} / \mathrm{w}$.)

were $0.26 \mathrm{mS} \mathrm{cm}^{-1}, 0.35 \mathrm{mS} \mathrm{cm}^{-1}$ and $0.50 \mathrm{mS} \mathrm{cm}^{-1}$ at room temperature for PC, EC/PC and EC/DMC, respectively. PLTB@PVDF-HFP membrane soaked in $\mathrm{EC} / \mathrm{DMC}$ possessed the optimal ionic conductivity over the range of $10{ }^{\circ} \mathrm{C}$ to $80{ }^{\circ} \mathrm{C}$, so we chose EC/DMC soaked PLTB@ PVDF-HFP membranes for further research in our experiments.

For traditional liquid electrolytes incorporated with polyolefin separators, the apparent ionic conductivities at room temperature generally kept at $0.1-1 \mathrm{mS} \mathrm{cm}^{-1}$ and the lithium ion transference numbers ranged from 0.2 to 0.4 , depending on the properties of salts and solvents (for example, $1 \mathrm{M} \mathrm{LiPF}_{6}$-EC/DMC using Celgard 2500 as separator, $\sigma=$ $0.85 \mathrm{mS} \mathrm{cm}^{-1}, t_{\mathrm{Li}+}=0.32$ ) [10]. A lithium ion transference number significantly less than 1.0 is certainly undesired, because the resultant overwhelming anion movement and enrichment near electrode surfaces would cause concentration polarization during battery operation. In addition, taking lithium ion transference number into consideration, the solvent swollen PLTB@PVDF-HFP delivered much higher lithium ionic conductivity $\left(0.455 \mathrm{mS} \mathrm{cm}^{-1}\right)$ than that of traditional liquid electrolytes $\left(0.27 \mathrm{mS} \mathrm{cm}{ }^{-1}\right)$. Lithium ionic conductivity comparison for both electrolyte systems was listed in Table 1 . The results indicated that this kind of gel polymer electrolyte could endow superior battery performance.

\subsection{Electrochemical stability and $\mathrm{Li}^{+}$transference number of EC/DMC swollen PLTB@PVDF-HFP membrane}

The electrochemical stability of EC/DMC swollen PLTB@PVDF-HFP membrane was measured by the cyclic voltammetry. It could be seen from Fig. 3(a) that the EC/DMC swollen PLTB@PVDF-HFP membrane didn't oxidatively decompose until $5.0 \mathrm{~V} \mathrm{vs.} \mathrm{Li}^{+} / \mathrm{Li}$ at $20^{\circ} \mathrm{C}$. Also, the EC/DMC swollen PLTB@PVDF-HFP membrane showed very excellent lithium deposition-stripping performance. The transference number of $\mathrm{Li}^{+}$was measured and calculated to be 0.91 using the steady-state current method (see Fig. 3(b)). This remarkably high transference number was attributed to the polyanion structure of the PLTB.

\subsection{Battery performance of Li/PLTB@PVDF-HFP/Li $\mathrm{L}_{4} \mathrm{Ti}_{5} \mathrm{O}_{12}$ half cell}

As a promising anode material for lithium ion batteries, spinel $\mathrm{Li}_{4} \mathrm{Ti}_{5} \mathrm{O}_{12}$ exhibits many advantages compared to the currently used

Table 1

Apparent ionic conductivity comparison for both electrolyte systems.

\begin{tabular}{|c|c|c|c|c|c|}
\hline \multicolumn{3}{|c|}{$1 \mathrm{M} \mathrm{LiPF}_{6}-\mathrm{EC} / \mathrm{DMC}$ (with separator) } & \multicolumn{3}{|c|}{ EC/DMC swollen PLTB@PVDF-HFP } \\
\hline$\sigma / \mathrm{mS} \mathrm{cm}^{-1}$ & $t_{\mathrm{Li}}^{+}$ & $\sigma_{\mathrm{Li}}^{+\mathrm{a}} / \mathrm{mS} \mathrm{cm}^{-1}$ & $\sigma / \mathrm{mS} \mathrm{cm}^{-1}$ & $t_{\mathrm{Li}}^{+}$ & $\sigma_{\mathrm{Li}}^{+} / \mathrm{mS} \mathrm{cm}^{-1}$ \\
\hline 0.85 & 0.32 & 0.27 & 0.50 & 0.91 & 0.455 \\
\hline
\end{tabular}


(a)

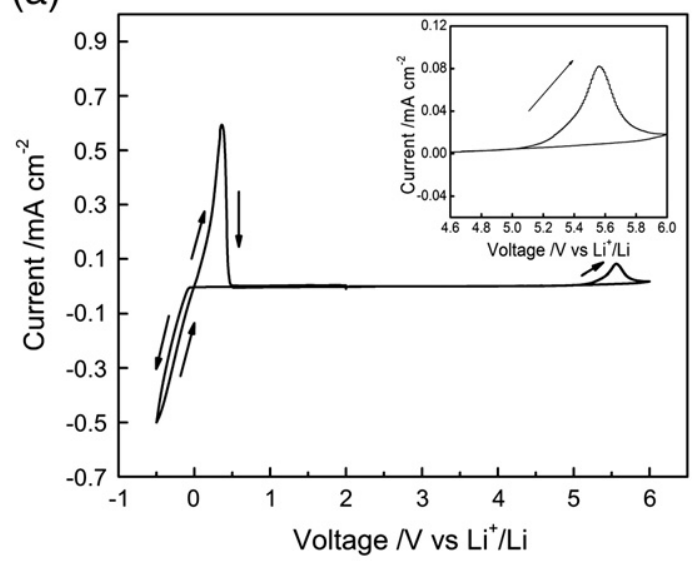

(b)

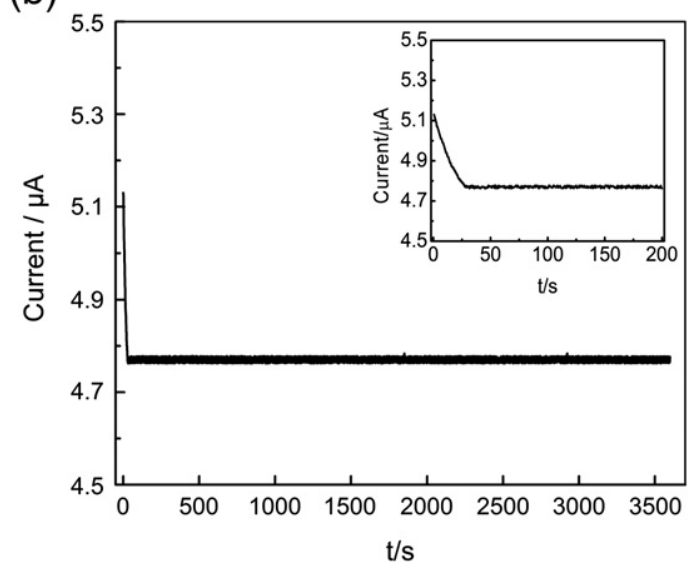

Fig. 3. (a) Electrochemical stability of EC/DMC swollen PLTB@PVDF-HFP membrane at $20{ }^{\circ} \mathrm{C}$ ( scan rate $=0.1 \mathrm{mV} \mathrm{s}^{-1}$ ) and (b) variation of current with time during polarization of a Li//EC/DMC swollen PLTB@PVDF-HFP membrane//Li cell at $20{ }^{\circ} \mathrm{C}$, with total applied potential difference of $10 \mathrm{mV}$.

graphite. For example, there is negligible volume change in the unit cell volume of $\mathrm{Li}_{4} \mathrm{Ti}_{5} \mathrm{O}_{12}$ during lithium insertion and extraction, so it was named as zero strain material. It also has a high voltage plateau at around $1.55 \mathrm{~V} \mathrm{vs}$. $\mathrm{Li}^{+} / \mathrm{Li}$. Therefore, $\mathrm{Li}_{4} \mathrm{Ti}_{5} \mathrm{O}_{12}$ is much safer and more stable than carbon-based materials. In spite of gasing problem, the carbon-coated $\mathrm{Li}_{4} \mathrm{Ti}_{5} \mathrm{O}_{12}$ was reported to possess good cycling performance. Fig. 4(a) showed the first charge/discharge voltage profiles of Li//EC/DMC swollen PLTB@PVDF-HFP// $\mathrm{Li}_{4} \mathrm{Ti}_{5} \mathrm{O}_{12}$ at the temperature of $20{ }^{\circ} \mathrm{C}$ and $60{ }^{\circ} \mathrm{C}$, and a stable voltage plateau at around $1.55 \mathrm{~V}$ vs. $\mathrm{Li}^{+} / \mathrm{Li}$ could be observed for both of them. The cycling performances of $\mathrm{Li} / \mathrm{Li}_{4} \mathrm{Ti}_{5} \mathrm{O}_{12}$ half cells using EC/DMC swollen PLTB@PVDF-HFP and $1 \mathrm{M} \mathrm{LiPF}_{6}-\mathrm{EC} / \mathrm{DMC}$ were shown in Fig. $4(\mathrm{~b})$, where the charge/discharge rates were fixed at $0.5 \mathrm{C}$. The discharge capacity of the cells could retain $142.2 \mathrm{mAh} \mathrm{g}^{-1}$ (calculated on the mass of $\mathrm{Li}_{4} \mathrm{Ti}_{5} \mathrm{O}_{12}$ ) and $138.7 \mathrm{mAh} \mathrm{g}^{-1}$ for $\mathrm{LiPF}_{6}$-based electrolyte and EC/DMC swollen PLTB@PVDF-HFP after 60 cycles at $20^{\circ} \mathrm{C}$, respectively. The capacity retention, $R_{60 / 1}$, defined as ratio of capacity at 60th cycle over that at first cycle, was $98.1 \%$ and $92.8 \%$, respectively. However, the discharge capacity of gel PLTB@PVDF-HFP cells could retain $146.4 \mathrm{mAh} \mathrm{g}^{-1}$ after 60 cycles and $R_{60 / 1}$ was $99.0 \%$ at high temperature of $60{ }^{\circ} \mathrm{C}$. It could be seen that the $\mathrm{Li} / \mathrm{Li}_{4} \mathrm{Ti}_{5} \mathrm{O}_{12}$ cells using EC/DMC swollen PLTB@PVDF-HFP membranes were comparable to those using $\mathrm{LiPF}_{6}$ based liquid electrolytes.

\subsection{Battery performance of $\mathrm{Li}_{4} \mathrm{Ti}_{5} \mathrm{O}_{12} / \mathrm{PLTB} @ P V D F-H F P / L i F e P \mathrm{P}_{4}$ cell}

The initial charge/discharge performances of $\mathrm{Li}_{4} \mathrm{Ti}_{5} \mathrm{O}_{12} / / \mathrm{EC} / \mathrm{DMC}$ swollen PLTB@PVDF-HFP//LiFePO ${ }_{4}$ cells at $20{ }^{\circ} \mathrm{C}$ and $60{ }^{\circ} \mathrm{C}$ were (a)

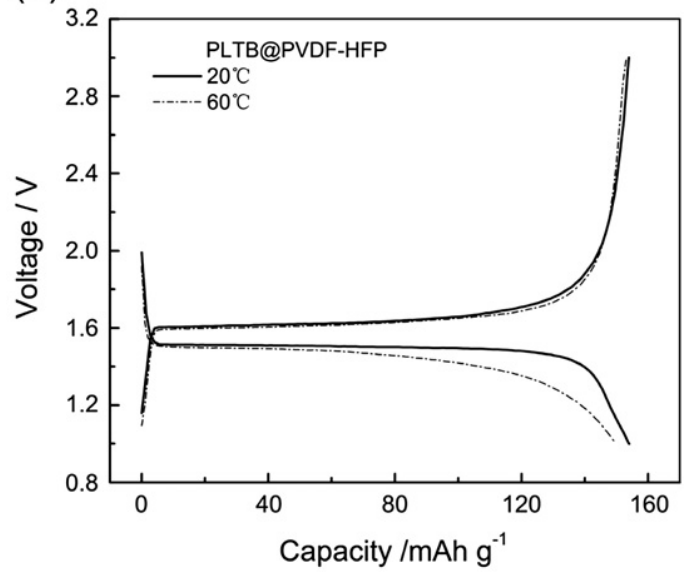

(b)

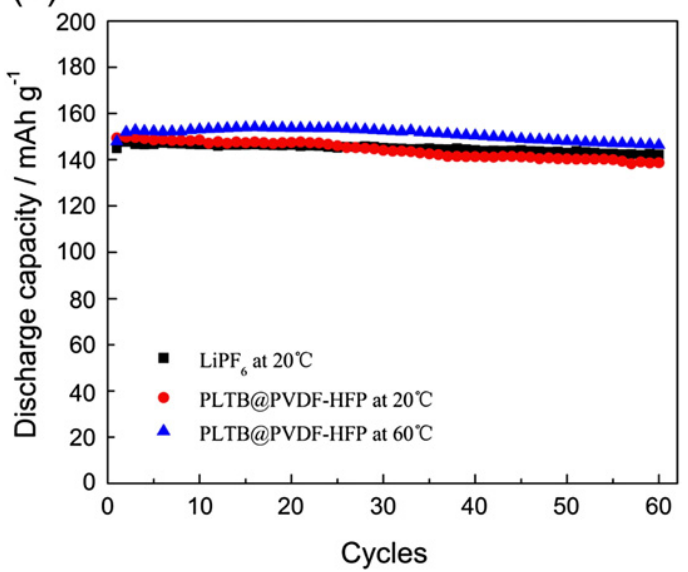

Fig. 4. (a) The first charge/discharge voltage profiles of Li//EC/DMC swollen PLTB@ PVDF-HFP// $\mathrm{Li}_{4} \mathrm{Ti}_{5} \mathrm{O}_{12}$ cell and (b) cycling stability of $\mathrm{Li} / / \mathrm{EC} / \mathrm{DMC}$ swollen PLTB@ PVDF-HFP//Li ${ }_{4} \mathrm{Ti}_{5} \mathrm{O}_{12}$ cells and $\mathrm{Li} / / \mathrm{LiPF}_{6}-\mathrm{EC} / \mathrm{DMC} / / \mathrm{Li}_{4} \mathrm{Ti}_{5} \mathrm{O}_{12}$ cell at $20{ }^{\circ} \mathrm{C}$ or $60{ }^{\circ} \mathrm{C}$. Rate: $0.5{ }^{\circ} \mathrm{C}$.

presented in Fig. 5(a) and (b), respectively. Both $\mathrm{Li}_{4} \mathrm{Ti}_{5} \mathrm{O}_{12} / / \mathrm{EC} / \mathrm{DMC}$ swollen PLTB@PVDF-HFP//LiFePO 4 cells had stable charge/discharge plateaus at $20^{\circ} \mathrm{C}$ and $60{ }^{\circ} \mathrm{C}$, which meant that PLTB@PVDF-HFP based polymer electrolyte had good interface compatibility with $\mathrm{Li}_{4} \mathrm{Ti}_{5} \mathrm{O}_{12}$ and $\mathrm{LiFePO}_{4}$ electrodes. The polarization and resultant voltage difference of PLTB@ PVDF-HFP based cells was comparable to that of $\mathrm{LiPF}_{6}$ electrolyte based cells under $0.5 \mathrm{C}$ at ambient temperature. This was absolutely attributed to the excellent lithium ion conductivity of PLTB@PVDF-HFP electrolyte. While, at the elevated temperature of $60{ }^{\circ} \mathrm{C}$, the $\mathrm{Li}_{4} \mathrm{Ti}_{5} \mathrm{O}_{12} / \mathrm{LiFePO}_{4}$ cell using $\mathrm{LiPF}_{6}-\mathrm{EC} / \mathrm{DMC}$ electrolyte failed to be initially charged and discharged smoothly. The discharge voltage profiles of PLTB@PVDF-HFP based cells at different discharge rates were depicted in Fig. 5(c) under $20^{\circ} \mathrm{C}$. It could be seen that the discharge capacities of the cells were $134.6 \mathrm{mAh} \mathrm{g}{ }^{-1}$ (based on the mass of $\mathrm{LiFePO}_{4}$ and the geometric current density $\left.25.5 \mu \mathrm{A} / \mathrm{cm}^{2}\right), 132.9 \mathrm{mAh} \mathrm{g}^{-1}\left(51 \mu \mathrm{A} / \mathrm{cm}^{2}\right), 123.6 \mathrm{mAh} \mathrm{g}^{-1}$ $\left(127 \mu \mathrm{A} / \mathrm{cm}^{2}\right)$ and $104.9 \mathrm{mAh} \mathrm{g}^{-1}\left(255 \mu \mathrm{A} / \mathrm{cm}^{2}\right)$, respectively. These results demonstrated that the $\mathrm{Li}_{4} \mathrm{Ti}_{5} \mathrm{O}_{12} / / \mathrm{EC} / \mathrm{DMC}$ swollen PLTB@PVDF$\mathrm{HFP} / / \mathrm{LiFePO}_{4}$ cells had a considerable rate performance even at room temperature.

Fig. 6 showed the cycling performances of $\mathrm{Li}_{4} \mathrm{Ti}_{5} \mathrm{O}_{12} / \mathrm{LiFePO}_{4}$ cells using EC/DMC swollen PLTB@PVDF-HFP as electrolyte with the charge/ discharge rates fixed at $0.5 \mathrm{C}$. It could be seen from Fig. 6(a) and (c) that the capacities of the cells using the polymer electrolyte retained $116.5 \mathrm{mAh} \mathrm{g}^{-1}$ at $20{ }^{\circ} \mathrm{C}$ and $101.6 \mathrm{mAh} \mathrm{g}^{-1}$ at $60{ }^{\circ} \mathrm{C}$ after 100 cycles. In the capacity retention, $R_{100 / 1}$ was $86.6 \%$ and $86.3 \%$ respectively. For $\mathrm{LiPF}_{6}$ based cell at $20^{\circ} \mathrm{C}$, the discharge capacity was $110.3 \mathrm{mAh} \mathrm{g}{ }^{-1}$ at 
(a)

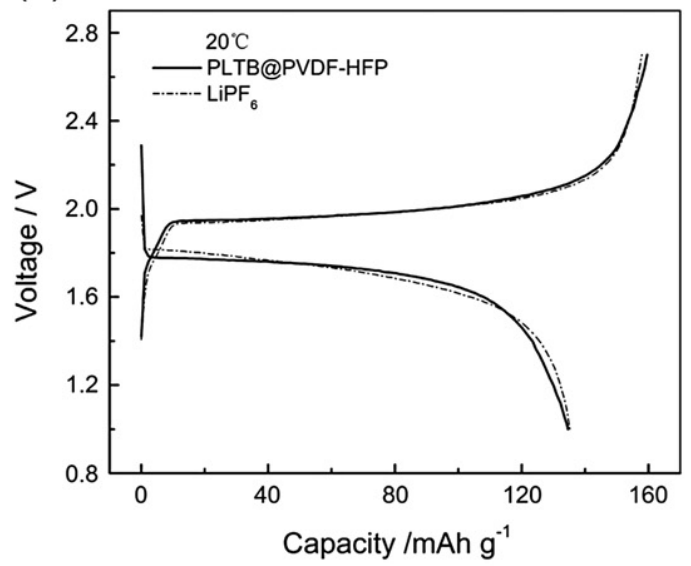

(b)

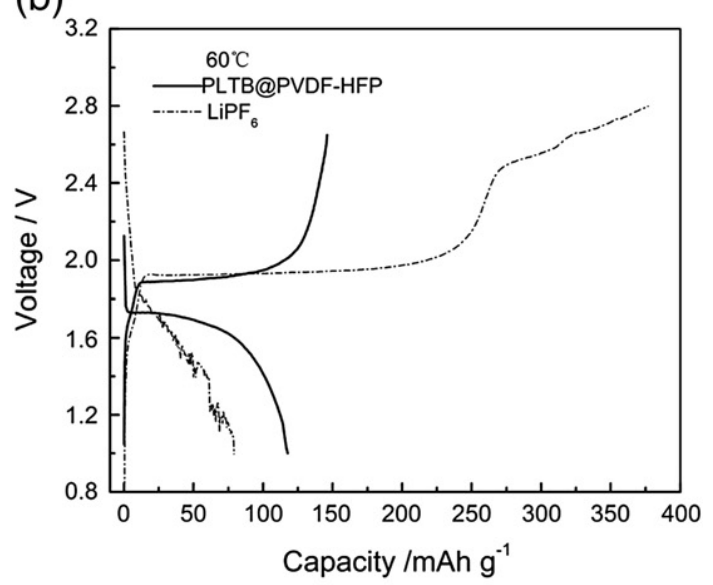

(c)

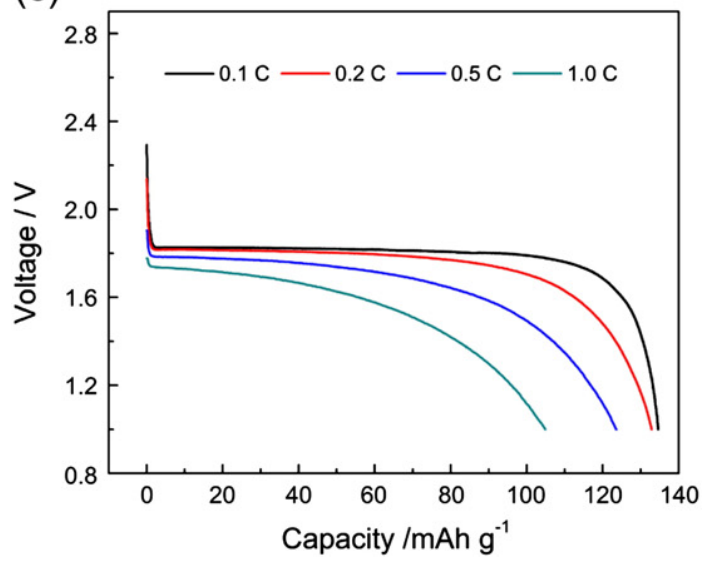

Fig. 5. The first charge/discharge curves of $\mathrm{Li}_{4} \mathrm{Ti}_{5} \mathrm{O}_{12} / / \mathrm{EC} / \mathrm{DMC}$ swollen PLTB@PVDF-HFP// LiFePO ${ }_{4}$ cells at (a) $20{ }^{\circ} \mathrm{C}$ and (b) $60{ }^{\circ} \mathrm{C}$, rate: $0.5{ }^{\circ} \mathrm{C}$. (c) Discharge voltage profiles of $\mathrm{Li}_{4} \mathrm{Ti}_{5} \mathrm{O}_{12} / / \mathrm{EC} / \mathrm{DMC}$ swollen PLTB@PVDF-HFP//LiFePO 4 cells at different discharge rates. Temperature: $20{ }^{\circ} \mathrm{C}$

the 100th cycle and the discharge capacity retention was about $81.6 \%$. The initial coulombic efficiencies were very similar for both PLTB@ PVDF-HFP based cells (84.3\%) and $\mathrm{LiPF}_{6}$ based cells (85.6\%) at room temperature (Fig. 6(b)). At the temperature of $60{ }^{\circ} \mathrm{C}$, the coulombic efficiency of the first cycle for PLTB@PVDF-HFP based cell was 80.4\% (Fig. 6(c)). All the other coulombic efficiencies of $\mathrm{Li}_{4} \mathrm{Ti}_{5} \mathrm{O}_{12} / / \mathrm{EC} / \mathrm{DMC}$ swollen PLTB@ PVDF-HFP//LiFePO 4 cells were nearly approaching to $100 \%$ in the following cycles, which could be seen from Fig. 6(b) and (c). However, both the capacities and the coulombic efficiencies of $\mathrm{LiPF}_{6}$ based cell showed (a)

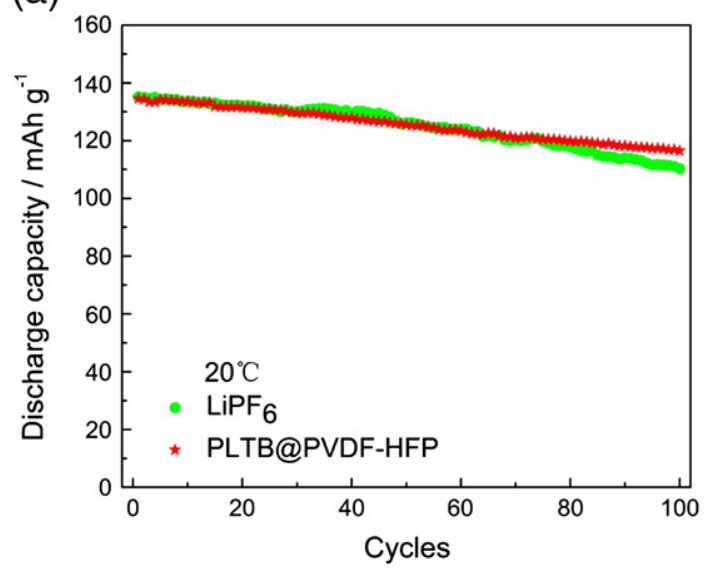

(b)

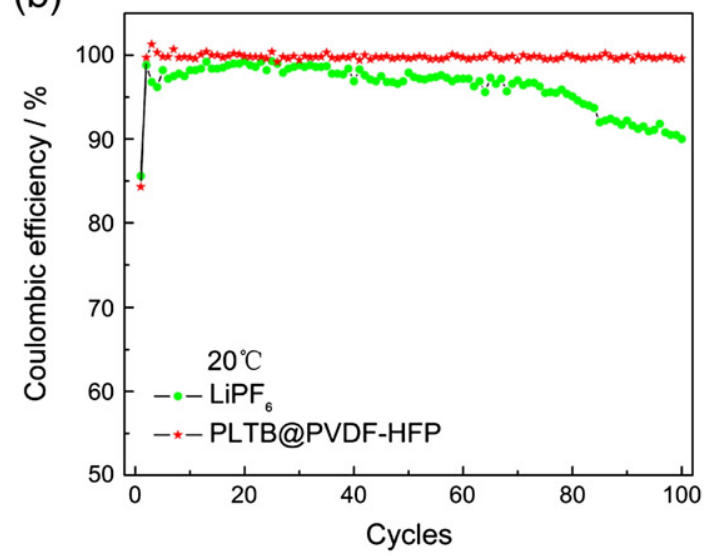

(c)

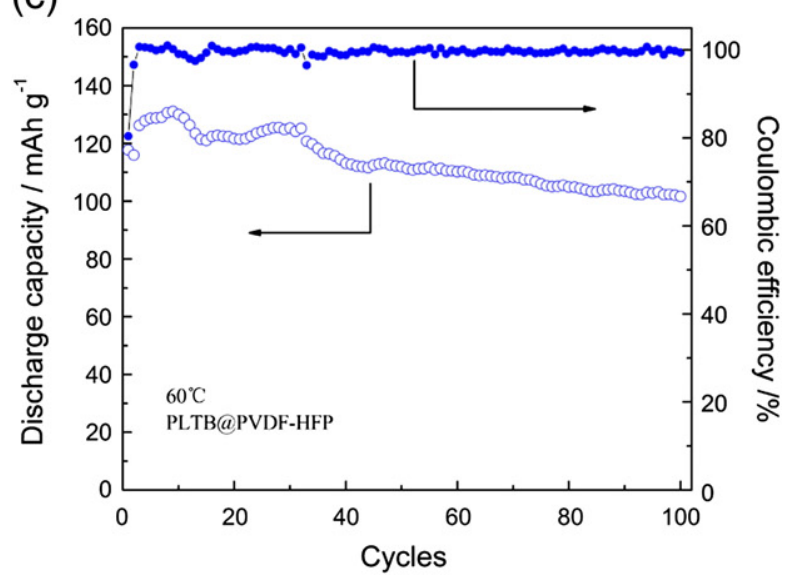

Fig. 6. (a) Cycling stability and (b) coulombic efficiencies of $\mathrm{Li}_{4} \mathrm{Ti}_{5} \mathrm{O}_{12} / / \mathrm{EC} / \mathrm{DMC}$ swollen PLTB@PVDF-HFP//LiFePO 4 cell and $\mathrm{Li}_{4} \mathrm{Ti}_{5} \mathrm{O}_{12} / / \mathrm{LiPF}_{6}-\mathrm{EC} / \mathrm{DMC} / / \mathrm{LiFePO}_{4}$ cell at $20{ }^{\circ} \mathrm{C}$, (c) cycling stability and coulombic efficiencies of $\mathrm{Li}_{4} \mathrm{Ti}_{5} \mathrm{O}_{12} / / \mathrm{EC} / \mathrm{DMC}$ swollen PLTB@PVDF-HFP// LiFePO ${ }_{4}$ cell at $60{ }^{\circ} \mathrm{C}$.

accelerated fading from about the 60 th cycle at $20^{\circ} \mathrm{C}$. This implied that the SEI layer in PLTB@PVDF-HFP based cells was more stable and compatible than that in $\mathrm{LiPF}_{6}$ based cells. Besides, the SEI layer exhibited a good thermal stability. Therefore, it was demonstrated that the cycling performance of PLTB@PVDF-HFP based cell were much enhanced than those of $\mathrm{LiPF}_{6}$ based cell.

To further investigate the superior cycling performance of EC/DMC swollen PLTB@PVDF-HFP in $\mathrm{Li}_{4} \mathrm{Ti}_{5} \mathrm{O}_{12} / \mathrm{LiFePO}_{4}$ cells, the surface morphology of $\mathrm{LiFePO}_{4}$ electrode was studied by SEM after long battery 

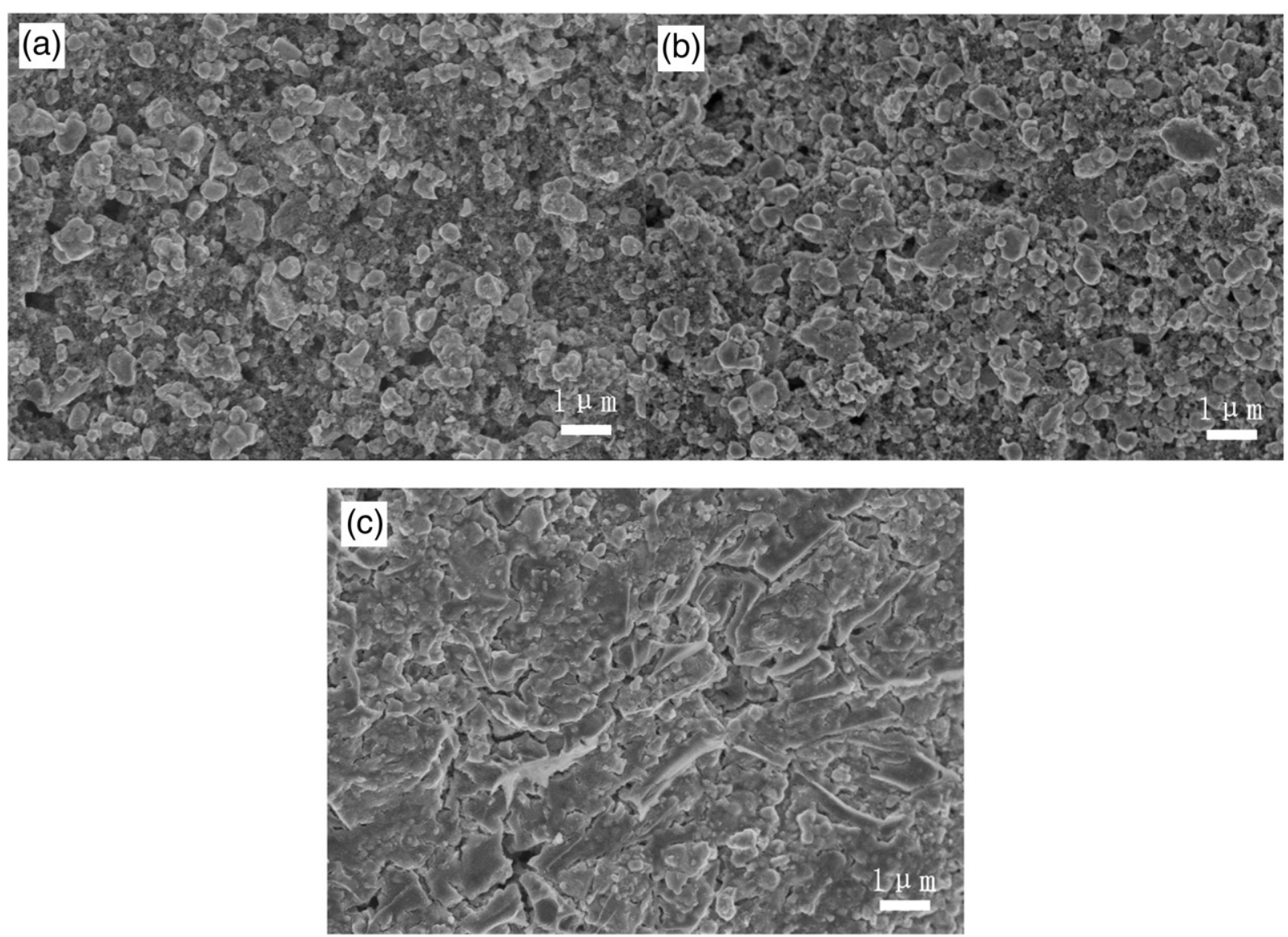

Fig. 7. SEM images of (a) pristine $\mathrm{LiFePO}_{4}$ electrode, (b) the $\mathrm{LiFePO}_{4}$ electrode from $\mathrm{Li}_{4} \mathrm{Ti}_{5} \mathrm{O}_{12} / / \mathrm{EC} / \mathrm{DMC}$ swollen PLTB@PVDF-HFP//LiFePO 4 cell after 100 cycles at $60{ }^{\circ} \mathrm{C}$ and $\left(\mathrm{c}\right.$ ) the $\mathrm{LiFePO}_{4}$ electrode from $\mathrm{Li}_{4} \mathrm{Ti}_{5} \mathrm{O}_{12} / / \mathrm{LiPF}_{6}-\mathrm{EC} / \mathrm{DMC} / / \mathrm{LiFePO}_{4}$ cell after 100 cycles at $50{ }^{\circ} \mathrm{C}$.

cycles at $0.5 \mathrm{C}$, which was depicted in Fig. 7. For comparison, the surface morphology of $\mathrm{LiFePO}_{4}$ electrodes after cycling using $\mathrm{LiPF}_{6}-\mathrm{EC} / \mathrm{DMC}$ as electrolyte at $50{ }^{\circ} \mathrm{C}$ was also provided. It could be observed that some of the $\mathrm{LiFePO}_{4}$ particles in the $\mathrm{LiFP}_{6}$ based cell were apparently corroded and cracked after 100 cycles (Fig. 7(c)). While, the surface morphology of LiFePO ${ }_{4}$ electrode in PLTB@PVDF-HFP based cell after 100 cycles at $60{ }^{\circ} \mathrm{C}$ (Fig. 7(b)) were almost the same as that of the pristine $\mathrm{LiFePO}_{4}$ electrode (Fig. 7(a)). This implied that PLTB@PVDF-HFP based electrolyte was quite stable and compatible with $\mathrm{LiFePO}_{4}$ electrode without noticeable corrosion after a long cycling time. The main reason for the slight decrease of discharge capacity after the repeated cycles was from the occurrence of the irreversible phase and structure within active material LiFePO4, not related to the PLTB@PVDF-HFP electrolyte $[37,38]$.

\section{Conclusions}

In summary, a high performance single-ion polymer electrolyte based on EC/DMC swollen PLTB@PVDF-HFP was investigated and compared with that of $\mathrm{LiPF}_{6}$ based electrolyte. The EC/DMC swollen PLTB@ PVDF-HFP exhibits a superior lithium ionic conductivity at room temperature $\left(\sigma_{\mathrm{Li}+}=0.45 \mathrm{mS} \mathrm{cm}^{-1}\right)$ and significantly high lithium ion transference number $\left(t_{\mathrm{Li}+}=0.91\right)$. The $\mathrm{Li}_{4} \mathrm{Ti}_{5} \mathrm{O}_{12} / \mathrm{LiFePO}_{4}$ full cells using EC/DMC swollen PLTB@PVDF-HFP membranes exhibit stable charge/discharge plateau with small voltage difference, satisfactory rate performance and excellent cycling performance at room temperature. These superior performances of EC/DMC swollen PLTB@ PVDFHFP could endow this class of gel polymer electrolyte an excellent candidate electrolyte for high power lithium ion batteries.

\section{Acknowledgments}

This work was supported by the National Basic Research Program of China (Grant No. 2011CB935700), the Instrument Developing Project of the Chinese Academy of Sciences (Grant No. YZ201137) and the Key Research Program of the Chinese Academy of Sciences (Grant No. KGZDEW-202-2).

\section{Appendix A. Supplementary data}

Supplementary data to this article can be found online at http://dx. doi.org/10.1016/j.ssi.2013.09.007.

\section{References}

[1] M. Armand, J.M. Tarascon, Nature 451 (2008) 652-657.

[2] G. Jeong, Y.U. Kim, H. Kim, Y.J. Kim, H.J. Sohn, Energy Environ. Sci. 4 (2011) 1986-2002.

[3] K. Zaghib, M. Dontigny, A. Guerfi, J. Trottier, J. Hamel-Paquet, V. Gariepy, K. Galoutov, J. Power. Sources 126 (2012) 192-200.

[4] Y.S. Kim, T.H. Kim, H. Lee, H.K. Song, Energy Environ. Sci. 4 (2011) 4038-4045.

[5] Z. Cai, Y. Liu, S. Liu, L. Li, Y. Zhang, Energy Environ. Sci. 5 (2012) 5690-5693.

[6] Z. Cai, Y. Liu, J. Zhao, L. Li, Y. Zhang, J. Zhang, J. Power. Sources 202 (2012) 341-346.

[7] T.H. Cho, M. Tanaka, H. Ohnishi, Y. Kondo, M. Yoshikazu, T. Nakamura, T. Sakai, J. Power. Sources 195 (2010) 4272-4277.

[8] X. Sun, H.S. Lee, X.Q. Yang, J.M. Breen, J. Electrochem. Soc. 146 (1999) 3655-3659.

[9] V. Aravindan, J. Gnanaraj, S. Madhavi, H.K. Liu, Chem. Eur. J. 17 (2011) 14326-14346.

[10] K. Xu, Chem. Rev. 104 (2004) 4303-4417.

[11] B. Scrosati, F. Croce, S. Panero, J. Power. Sources 100 (2001) 93-100.

[12] F.B. Dias, L. Plomp, J. Power. Sources 88 (2000) 169-191.

[13] Y.V. Bsckakova, O.V. Yarmolenko, O.N. Efimov, Russ. Chem. Rev. 81 (2012) 367-380.

[14] P. Zhang, L. Li, D. He, Y. Wu, S. Makoto, Acta Polym. Sin. 2 (2011) 125-131.

[15] N.A. Rossi, R. West, Polym. Int. 58 (2009) 267-272. 
[16] A.M. Stephan, Eur. Polym. J. 42 (2006) 21-42.

[17] W.H. Meyer, Adv. Mater. 10 (1998) 439-448.

[18] Y. Zhu, F. Wang, Y. Wu, Energy Environ. Sci. 6 (2013) 618-624.

[19] J. Cao, B. Zhu, Y. Xu, J. Membr. Sci. 281 (2006) 446-453.

[20] Y. Ding, P. Zhang, W. Di, J. Membr. Sci. 329 (2009) 56-59.

[21] H.S. Jeong, S.C. Hong, S.Y. Lee, J. Membr. Sci. 364 (2010) 177-182.

[22] D. Aurbach, Nonaqueous Electrochemistry, Marcel Dekker, Inc., New York, 1999.

[23] K.M. Abraham, J.L. Goldman, D.L. Natwig, J. Electrochem. Soc. 129 (1982) 2404-2409.

[24] S. Sloop, J. Pugh, S. Wang, Electrochem. Solid-State Lett. 4 (2001) A42-A44.

[25] W. Xu, C.A. Angell, Electrochem. Solid-State Lett. 4 (2001) E1-E4.

[26] K. Xu, S. Zhang, T.R. Jow, W. Xu, C.A. Angell, Electrochem. Solid-State Lett. 5 (2002) A26-A29.
[27] V. Aravindan, P. Vickraman, Ionics 4 (2007) 277-280

[28] W. Xu, J.P. Belieres, C.A. Angell, Chem. Mater. 13 (2001) 575-580.

[29] W. Xu, C.A. Angell, Solid State Ionics 147 (2002) 295-301.

[30] W. Xu, M.D. Williams, C.A. Angell, Chem. Mater. 14 (2002) 401-409.

[31] Y.S. Zhu, X.J. Wang, Y.P. Wu, Electrochim. Acta 87 (2013) 113-118.

[32] Y.S. Zhu, X.W. Gao, Y.P. Wu, Electrochem. Commun. 22 (2012) 29-32.

[33] X. Wang, Z. Liu, C. Zhang, G. Cui, Electrochim. Acta 92 (2013) 132-138.

[34] J. Evants, C.A. Vincent, P.G. Bruce, Polymer 28 (1987) 2324-2328.

[35] Y. Liu, Z. Cai, L. Li, Energy Environ. Sci. 5 (2012) 9007-9013.

[36] E.S. Choi, S.Y. Lee, J. Mater. Chem. 21 (2011) 14747-14754.

[37] A.K. Padhi, K.S. Nanjundaswamy, J.B. Goodenough, J. Electrochem. Soc. 144 (1997) 1188-1194.

[38] A.S. Andersson, J.O. Thomas, J. Power. Sources 97-98 (2001) (2001) 498-502. 